\title{
Effect of silage type and concentrate level on conjugated linoleic acids, trans-C18: 1 isomers and fat content in milk from dairy cows
}

\author{
Tina S. NIELSEN ${ }^{a *}$, Ellen M. STRAARUP ${ }^{\mathrm{b}}$, Mogens VeSTERGAARD ${ }^{\mathrm{a}}$, \\ Kris SEJRSEN ${ }^{\mathrm{a}}$ \\ ${ }^{a}$ Danish Institute of Agricultural Sciences, Research Centre Foulum, Department of Animal Health, \\ Welfare and Nutrition, PO Box 50, 8830 Tjele, Denmark \\ ${ }^{\mathrm{b}}$ BioCentrum, Technical University of Denmark, 2800 Lyngby, Denmark
}

(Received 11 January 2006; accepted 22 August 2006)

\begin{abstract}
The objective of the study was to examine how the fatty acid composition of milk especially concentrations of conjugated linoleic acids (CLA) and trans-C18:1 isomers and milk fat percentage were affected by silage type and concentrate level. Forty dairy cows were blocked and randomly assigned to one of four diets in a $2 \times 2$ factorial arrangement of treatments and a six week experimental period. Treatments were total mixed rations with maize $(\mathrm{M})$ or grass $(\mathrm{G})$ silage differing in polyunsaturated fatty acid (PUFA) profile and starch content, combined with a high $(\mathrm{H})$ or a low $(\mathrm{L})$ level of concentrate (with or without grain). Treatments had no significant effect on milk, protein and lactose yield, but energy corrected milk yield, milk fat percentage and fat yield was lower and protein percentage higher for maize compared with grass silage diets. Overall, maize silage diets resulted in higher concentrations of CLA isomers compared with grass silage diets, but there was a significant interaction between silage type and concentrate level for concentrations of cis9,trans11-CLA; trans10,cis12-CLA; trans11-C18:1 and trans10-C18:1. A high level of concentrate increased trans10,,cis12-CLA and trans10-C18:1 and reduced cis9,trans11-CLA and trans11-C18:1 when maize but not grass silage was provided. The results suggest that high levels of concentrate (grain) do not significantly alter the pattern of PUFA biohydrogenation in the rumen, the concentration of CLA and trans-C18:1 isomers in milk or cause milk fat depression unless combined with forage naturally high in starch and C18:2n-6 such as maize silage.
\end{abstract}

CLA / trans-C18:1 isomers / milk fat / silage type / concentrate level

\section{INTRODUCTION}

Numerous studies have indicated that consumption of conjugated linoleic acid (CLA) may be associated with positive effects on human health [1], and since milk and dairy products represent the primary source of CLA in the human diet [2] there

\footnotetext{
* Corresponding author:

TinaS.Nielsen@agrsci.dk
}

has been widespread interest in increasing milk fat CLA.

The major CLA isomer in milk fat is cis 9 ,trans 11 , which originates mainly by endogenous synthesis in the mammary gland from trans11-C18:1 via the enzyme $\Delta^{9}$-desaturase, whereas a minor proportion comes from escaped and absorbed cis 9 ,trans11-CLA produced in the rumen in the biohydrogenation of C18:2n-6 [1]. 
Trans11-C18:1 is the predominant transC18:1 fatty acid produced by incomplete biohydrogenation of dietary polyunsaturated fatty acids (C18:2n-6 and C18:3n-3; PUFA) under most dietary conditions [3]. However, diets that provide large amounts of readily digestible carbohydrates such as starch, with $[4,5]$ or without $[6,7]$ a supplement of vegetable oil often lead to increased proportions of trans 10-C18:1 and trans 10,cis12-CLA in milk fat. This response is usually caused by a decline in rumen $\mathrm{pH}[4,6]$ and shifts in the bacterial populations [8] whereby the biohydrogenation pathway of C18:2n-6 is altered [9]. Since mammals lack $\Delta^{12}$ desaturase enzyme activity in tissues [10], all trans 10 ,cis12-CLA in milk originates from ruminally produced trans 10 , cis 12 CLA with trans10-C18:1 being the subsequent product of hydrogenation.

Several studies have shown that increased proportions of trans 10,cis12-CLA and trans 10-C18:1 in milk are associated with milk fat depression $[4,7,11]$. Sufficient amounts of C18:2n-6 in the diet as substrate for potential trans10-C18:1 and trans 10 ,cis12-CLA production appears to be a prerequisite for milk fat depression to develop when high concentrate/low roughage diets are fed [4].

The effects of including oilseeds and plant oils with different PUFA profiles in high concentrate/low roughage diets on milk fat CLA concentration and milk fat depression have been thoroughly investigated $[4,5,12]$. Less well studied are the effects of commonly used forages differing in PUFA composition and starch content in combination with different levels of concentrate. Therefore the objective of the present study was to investigate how grass and maize silage with different PUFA profiles and starch content affected the fatty acid composition of milk, CLA isomers and certain trans-C18:1 fatty acids in particular, as well as milk fat percentage, when combined with a high or low level of concentrate.

\section{MATERIALS AND METHODS}

\subsection{Experimental design, animals and management}

Forty Holstein Friesian cows were grouped in 10 blocks according to parity, stage of lactation (i.e. days in milk post partum; DIM) and actual milk yield. Cows within each block were randomly assigned to one of four diets in a $2 \times 2$ factorial arrangement of treatments. In the beginning of the 6-week experimental period cows were on average 178 DIM ( $\mathrm{SD}=59$, range 17 to $231 \mathrm{~d}$ ) and yielding $25.5 \mathrm{~kg} . \mathrm{d}^{-1}$ of milk (SD $=3.5$, range 20.9 to $32.5 \mathrm{~kg} . \mathrm{d}^{-1}$ ). The cows were housed in individual tie stalls and fresh feed was offered ad libitum twice daily at 7.30 and $14.00 \mathrm{~h}$. Milking took place at 04.00 and $16.00 \mathrm{~h}$. During the first experimental week cows were switched from the herd diet to the experimental diets over a period of 3 days for adaptation. The experiment was carried out at the Foulum Research Centre from September to October 2003, and all experimental procedures were in compliance with Danish laws and regulations for the human care and use of animals in research (The Danish Ministry of Justice, Animal Testing Act [Consolidation Act No. 726, 1993, as amended by Act No. 1081, 1995]).

\subsection{Experimental diets}

Cows were offered total mixed rations containing grass $(\mathrm{G})$ or maize $(\mathrm{M})$ silage, as the only forage source, and a high $(\mathrm{H})$ or a low (L) level of concentrate resulting in the following experimental diets; GL, GH, ML and MH. Rolled barley, which is the most commonly used concentrate in 
Table I. Dry matter (DM) content and chemical composition (\% of DM) of silages and concentrates.

\begin{tabular}{lcccc}
\hline Dietary component & Maize silage & Grass silage & Rolled barley & Rapeseed cake \\
\hline DM, \% & 30.1 & 28.5 & 86.6 & 91.2 \\
Crude protein & 8.4 & 16.9 & 10.6 & 31.9 \\
Crude fat & 3.0 & 2.9 & 2.8 & 16.0 \\
NDF & 40.5 & 39.6 & 15.3 & 18.6 \\
Starch & 39.9 & 0.3 & 53.1 & 0.7 \\
cis 9 -C18: 1 & 0.6 & 0.07 & 0.4 & 8.5 \\
C18: $2 n-6$ & 1.2 & 0.3 & 1.6 & 3.3 \\
C18:3n-3 & 0.2 & 0.8 & 0.2 & 1.4 \\
Total FA & 2.5 & 1.7 & 3.0 & 14.7 \\
\hline
\end{tabular}

Danish dairy farming, was included in the two $\mathrm{H}$ diets at the expense of silage dry matter (DM). Rapeseed cake was included in all experimental diets as an additional source of protein, and in order to increase the overall amount of PUFA in the diets.

Grass silage was based on a mix of perennial ryegrass and clover, which was cut on June 3, 2003 and prewilted for $48 \mathrm{~h}$, then picked up by a precision-chop forage harvester and ensiled in a walled pit. Before closing the stack the surface was treated with an additive (GrasAAT Plus, Yara Formates, Lysaker, Norway) containing $9 \%$ propionic acid and $2 \%$ benzoic acid at 2 liter $/ \mathrm{m}^{2}$. Forage maize (variety Passat) was harvested on September 19, 2002 using a forage harvester fitted with grain crackers $(4.5 \mathrm{~mm})$ in a cutting length of $9.6 \mathrm{~mm}$ and ensiled directly without additives in a walled pit. The DM content and chemical composition of silages and concentrates are presented in Table I. Compared with grass silage, maize silage had a substantially higher starch and lower crude protein content, but silages were quite similar in neutral-detergent fiber (NDF) content. Grass silage contained relatively high proportions of $\mathrm{C} 18: 3 n-3$ whereas $\mathrm{C} 18: 2 n-6$ was the predominant $\mathrm{C} 18$ fatty acid in maize silage and barley (Tab. I).

Dietary composition, DM content and chemical composition of the four experimental diets are given in Table II. The
DM content and chemical composition of the experimental diets was calculated from the DM content and chemical composition of individual feedstuffs (Tab. I). The diets were formulated to have the same fill and amount of fatty acids per Scandinavian feed unit [13], and to meet requirements for protein (the AAT/PBV evaluation system) and other nutrients and minerals according to Danish recommendations [13]. However, compared with $\mathrm{G}$ diets, $\mathrm{M}$ diets had a slightly higher content of total fatty acids (Tab. II), which was due to a higher than expected level of total fatty acids in maize silage. The DM content of silages was determined weekly in order to adjust dietary formulations to account for small changes in the DM content if necessary.

\subsection{Recordings, sampling and analysis}

The feed intake of individual cows was recorded daily using feed weighbacks after the morning milking, but only data collected during the last 4 weeks of the experimental period were included in the statistical analysis, due to the temporal pattern in milk fat percentage (Fig. 1). Each week, samples of silages, rolled barley and rapeseed cake were obtained and frozen. Samples of individual feedstuffs from weeks 1 to 3 and 4 to 6 of the experiment were mixed, and a representative 
Table II. Ingredients and chemical composition of grass (G) and maize (M) silage diets with a low $(\mathrm{L})$ or a high $(\mathrm{H})$ level of concentrate.

\begin{tabular}{|c|c|c|c|c|}
\hline \multirow{3}{*}{$\begin{array}{l}\text { Silage type } \\
\text { Concentrate level }\end{array}$} & \multicolumn{4}{|c|}{ Dietary treatment } \\
\hline & \multicolumn{2}{|c|}{$\mathrm{G}$} & \multicolumn{2}{|c|}{ M } \\
\hline & $\mathrm{L}$ & $\mathrm{H}$ & $\mathrm{L}$ & $\mathrm{H}$ \\
\hline \multicolumn{5}{|c|}{ Ingredient (\% of DM) } \\
\hline Maize silage & - & - & 68.8 & 52.0 \\
\hline Grass silage & 72.7 & 52.7 & - & - \\
\hline Rolled barley & - & 18.3 & - & 16.2 \\
\hline Rapeseed cake & 27.0 & 28.3 & 30.2 & 30.6 \\
\hline Mineral mix ${ }^{1}$ & 0.19 & 0.54 & 0.89 & 1.14 \\
\hline Vitamin $\operatorname{mix}^{2}$ & 0.16 & 0.14 & 0.14 & 0.12 \\
\hline \multicolumn{5}{|c|}{ Chemical composition (\% of DM) } \\
\hline $\mathrm{DM}, \%$ & 35.0 & 41.9 & 38.9 & 45.5 \\
\hline Crude protein & 20.9 & 19.9 & 15.4 & 15.8 \\
\hline Crude fat & 6.5 & 6.6 & 6.9 & 6.9 \\
\hline Starch & 0.38 & 10.1 & 20.8 & 24.4 \\
\hline NDF & 33.8 & 29.0 & 33.4 & 29.2 \\
\hline C18:0 & 0.10 & 0.10 & 0.12 & 0.11 \\
\hline cis9-C18:1 & 2.35 & 2.51 & 2.99 & 2.98 \\
\hline $\mathrm{C} 18: 2 n-6$ & 1.11 & 1.40 & 1.80 & 1.88 \\
\hline $\mathrm{C} 18: 3 n-3$ & 0.96 & 0.85 & 0.52 & 0.53 \\
\hline Total fatty acids & 5.2 & 5.6 & 6.2 & 6.3 \\
\hline $\mathrm{NE}^{3}, \mathrm{MJ} / \mathrm{kg} \mathrm{DM}$ & 7.57 & 7.97 & 7.18 & 7.57 \\
\hline
\end{tabular}

${ }^{1}$ Contained $20 \% \mathrm{Ca}, 10 \% \mathrm{P}, 4 \% \mathrm{Mg}, 0.3 \% \mathrm{Zn}, 0.001 \% \mathrm{Se}, 400 \mathrm{IU}$ of vit. A, $70 \mathrm{IU}$ of vit. D.g ${ }^{-1}$.

${ }^{2}$ Contained 5000 IU of vit. A, 200 IU vit. $\mathrm{D}_{3}, 1 \%$ vit. E.g ${ }^{-1}$.

${ }^{3}$ Net energy (NE) for lactation is based on Scandinavian Feed Units (SFU) (7.89 MJ NE $=1 \mathrm{SFU}$ ).

sample from the two periods was taken for determination of DM and for chemical analysis. Since the chemical composition of feedstuff in the two periods showed very little variation, an average of results was used for further calculations.

Milk yield was recorded twice weekly on two consecutive days where milk samples were obtained and stored at $4{ }^{\circ} \mathrm{C}$ with a preservative tablet (Microtabs 2; D\&F Control System, San Ramon, CA, USA) until analysis at the Sønderjysk Kontrol- forening laboratory (Vojens, Denmark) for fat, protein and lactose with near infrared procedures using a Milko Scan 54 analyser (Foss Electrics, Hillerød, Denmark). Milk samples for fatty acid analysis were collected in week 0 (before cows were switched to the experimental diets) and in weeks 2, 4 and 6 of the experimental period from two consecutive morning and afternoon milkings. The morning and afternoon milk samples were mixed and stored at $-20{ }^{\circ} \mathrm{C}$ until fatty acid analysis. 


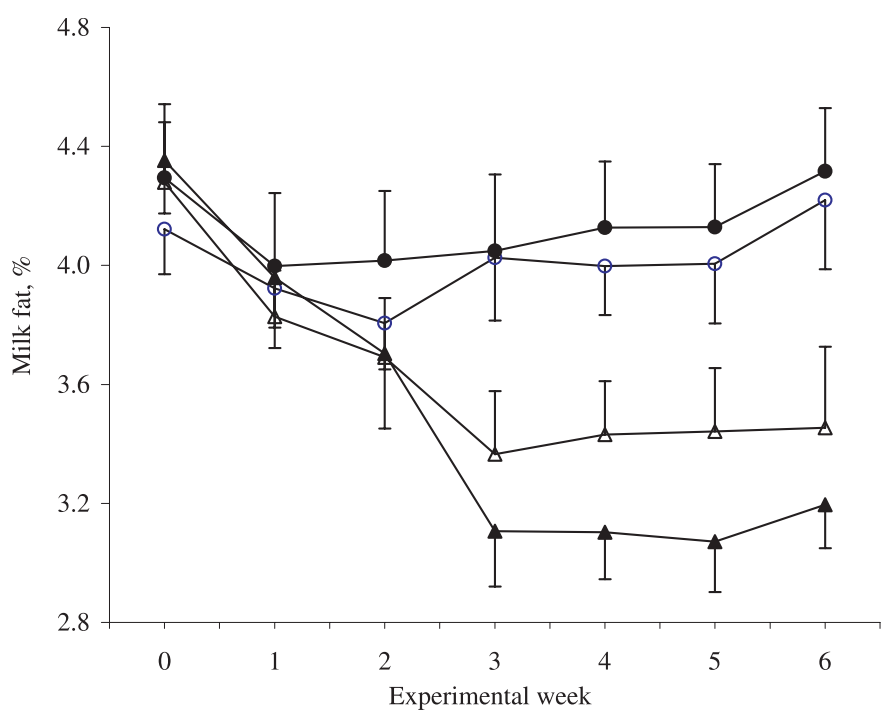

Figure 1. Temporal pattern of milk fat percentage. Dietary treatments were GL $(\mathrm{O}) \mathrm{GH}(\bullet)$, $\operatorname{ML}(\triangle)$ and $\mathrm{MH}(\boldsymbol{\Delta})$. Values represent means $\pm \mathrm{SE}$ for each treatment group $(n=10)$.

Lipid extraction of milk fat was performed according to methods described earlier [14], and methyl esters of the fatty acids were prepared by transesterification with $\mathrm{KOH}$ [15]. Fatty acid methyl esters (FAME) were separated and identified by a gas-liquid chromatograph (HP 6890 Hewlett-Packard GmbH, Waldbronn, Germany) equipped with a $\mathrm{CP}$ Select CB for FAME capillary column $(100 \mathrm{~m} \times 0.25 \mathrm{~mm}$ i.d. with $0.25 \mu \mathrm{m}$ film thickness) (Chrompack, Middleburg, The Netherlands). The oven temperature was initially $50{ }^{\circ} \mathrm{C}$ for $5 \mathrm{~min}$ then raised at $10{ }^{\circ} \mathrm{C} \cdot \mathrm{min}^{-1}$ to $165{ }^{\circ} \mathrm{C}$ (held for $40 \mathrm{~min}$ ). The temperature was then raised again at $1{ }^{\circ} \mathrm{C} \cdot \mathrm{min}^{-1}$ to $180{ }^{\circ} \mathrm{C}$ and at $10{ }^{\circ} \mathrm{C} \cdot \mathrm{min}^{-1}$ to $200{ }^{\circ} \mathrm{C}$ (held for $6.5 \mathrm{~min}$ ). Injection and detection temperatures were maintained at $270{ }^{\circ} \mathrm{C}$. The flow rate for the helium carrier gas was $2 \mathrm{~mL} \cdot \mathrm{min}^{-1}$, and a split/splitless injector was used with a split ratio of 1:14. Fatty acids were identified and quantified using pure methyl ester standards, including CLA isomers (Nu-Chek Prep Inc., Elysian, MN). The chromatogram areas of
C4:0, C6:0, C8:0 and C10:0 FAME were corrected by response factors $(\mathrm{C} 4: 0-2.01$; C6:0-1.40; C8:0-1.16; C10:0-1.04).

\subsection{Statistics}

Data were analysed statistically as a $2 \times 2$ factor design with blocks using the GLM procedure of SAS (Version 5.1, Release 8.02 SAS Institute Inc., Cary, NC) according to the following model:

$$
Y_{\mathrm{ijk}}=\mu+S_{\mathrm{i}}+E_{\mathrm{j}}+(S \times E)_{\mathrm{ij}}+B_{\mathrm{k}}+\varepsilon_{\mathrm{ijk}}
$$

where $Y_{\mathrm{ijk}}$ is the observation, $\mu$ is the overall mean, $S_{\mathrm{i}}$ is the silage type $(i=1,2), E_{\mathrm{j}}$ is the energy level $(j=1,2),(S \times E)_{\mathrm{ij}}$ the interaction between silage type and energy level, $B_{\mathrm{k}}$ is the block $(k=1,2, \ldots, 10)$, and $\varepsilon_{\mathrm{ijk}}$ is the residual error.

The primary focus of the experiment was on the maximal effects of treatments rather than on the change in milk fatty acid composition and milk fat percentage over time. During the third experimental 
week, treatment effects on milk fat percentage became evident and remained stable throughout the experiment (Fig. 1). Because milk fat percentage and the fatty acid composition of milk were assumed to be related, data on all parameters from weeks three to six of the experiment were included in the statistical analysis in order to be consistent in the use of data. In the analysis of milk yield, energy corrected milk yield (ECM) and milk constituents, the pre-experimental value (week 0 ) of the parameter was included in the model as a covariate. Regression procedures were employed to explore the form of the relationship between milk fat percentage and individual CLA isomers of interest by the non linear (NLIN) procedure of SAS. All model fits were evaluated using mean square errors and examination of studentised residual plots.

\section{RESULTS}

Feed intake, milk yield and milk composition data are presented in Table III. Corresponding to the higher DM content of $\mathrm{H}$ diets (Tab. I), DM intake was higher for cows receiving $\mathrm{H}$ diets. There was a silage type by concentrate level interaction for the intake of starch and crude protein reflecting the differences in starch and crude protein content of the four diets (Tab. II), as well as differences in DM intake (Tab. III). As expected, the intake of C18:2n-6 was higher and the intake of $\mathrm{C} 18: 3 n-3$ was lower for $\mathrm{M}$ compared with $\mathrm{G}$ diets, but there was an interaction between silage type and concentrate level for the intake of C18:3n-3. $\mathrm{H}$ diets also resulted in higher intakes of C18:2n-6 than $\mathrm{L}$ diets. The intake of total $\mathrm{C} 18$ fatty acids was increased for $\mathrm{M}$ and $\mathrm{H}$ diets compared with $\mathrm{G}$ and $\mathrm{L}$ diets.

Milk yield was unaffected by treatment, but feeding $\mathrm{M}$ compared with $\mathrm{G}$ diets was associated with a marked decrease in milk fat percentage (mean 3.23 and $4.15 \%$, re- spectively) and a mean decrease in milk fat yield of $272 \mathrm{~g} . \mathrm{d}^{-1}$. Although not significant $(P=0.15)$, milk fat percentage tended to decrease with increased concentrate level, especially when maize silage was fed. The lower secretion of milk fat resulted in a significantly lower ECM for M compared with $\mathrm{G}$ diets (21.9 and $26.6 \mathrm{~kg} . \mathrm{d}^{-1}$, respectively) (Tab. III), but no effect of concentrate level was observed. The protein percentage of milk was lower for cows fed $\mathrm{G}$ and $\mathrm{L}$ diets compared with $\mathrm{M}$ and $\mathrm{H}$ diets, and the yield of protein tended $(P=0.06)$ to increase as the concentrate level increased. Lactose contents and yields were unaffected by treatment (Tab. III).

The fatty acid composition of milk fat is presented in Table IV. G diets resulted in higher concentrations of short and medium-chain fatty acids $(\leq \mathrm{C} 16: 0)$ than $\mathrm{M}$ diets. Except for C4:0, the concentrate level did not affect short and mediumchain fatty acids. Relative to $\mathrm{M}$ diets, the $\mathrm{G}$ diets increased stearic acid (C18:0) and decreased levels of the monounsaturated fatty acids palmitoleic acid (cis9-C16:1) and oleic acid (cis9-C18:1).

Overall, $\mathrm{M}$ diets resulted in higher concentrations of cis 9 ,trans 11 and trans 10 ,cis 12 -CLA compared with the $\mathrm{G}$ diets, but there was a significant interaction between silage type and concentrate level for CLA-isomers and also for trans11C18:1 and trans10-C18:1. The ML diet resulted in the significantly highest cis9,trans11-CLA and trans11-C18:1 concentration, whereas trans10,cis12-CLA and trans $10-\mathrm{C} 18: 1$ concentrations were the highest in $\mathrm{MH}$ milk. Cis9,trans11CLA, trans10,cis12-CLA, trans11-C18:1 and trans $10-\mathrm{C} 18: 1$ were unaffected by the concentrate level when grass silage was fed (Tab. IV). There was a positive linear relationship between cis9,trans11-CLA and trans11-C18:1 $(y=0.34 x+0.45$, $\left.R^{2}=0.60, P<0.001\right)$ and between trans10,cis12-CLA and trans10-C18:1 $\left(y=0.003 x+0.012, R^{2}=0.91\right.$, 
Table III. Feed intake, milk yield and composition of cows fed grass (G) or maize (M) silage diets with a low $(\mathrm{L})$ or high $(\mathrm{H})$ level of concentrate.

\begin{tabular}{|c|c|c|c|c|c|c|c|c|}
\hline \multirow{3}{*}{$\begin{array}{l}\text { Silage type (S) } \\
\text { Concentrate level (C) }\end{array}$} & \multicolumn{4}{|c|}{ Dietary treatment ${ }^{1}$} & \multirow[b]{3}{*}{ SEM } & \multirow{2}{*}{\multicolumn{3}{|c|}{$P^{1}$}} \\
\hline & \multicolumn{2}{|c|}{ G } & \multicolumn{2}{|c|}{ M } & & & & \\
\hline & $\mathrm{L}$ & $\mathrm{H}$ & $\mathrm{L}$ & $\mathrm{H}$ & & $S$ & $\mathrm{C}$ & $\mathrm{S} \times \mathrm{C}$ \\
\hline \multicolumn{9}{|l|}{ Intake/d } \\
\hline DM, kg & 18.4 & 19.4 & 18.4 & 20.0 & 0.4 & 0.49 & $* *$ & 0.43 \\
\hline $\mathrm{NE}^{2}, \mathrm{MJ}$ & 139 & 154 & 132 & 151 & 3 & 0.11 & $* * *$ & 0.49 \\
\hline Starch, g & $70 \mathrm{a}$ & $1948 \mathrm{~b}$ & $3818 \mathrm{c}$ & $4874 \mathrm{~d}$ & 80 & $* * *$ & $* * *$ & $* * *$ \\
\hline Crude protein, $\mathrm{g}$ & $3845 \mathrm{a}$ & 3848 a & $2826 \mathrm{~b}$ & $3164 \mathrm{c}$ & 74 & $* * *$ & $*$ & $*$ \\
\hline $\mathrm{C} 18: 2 n-6, \mathrm{~g}$ & 211 & 275 & 345 & 390 & 7 & $* * *$ & $* * *$ & 0.19 \\
\hline $\mathrm{C} 18: 3 n-3, \mathrm{~g}$ & $180 \mathrm{a}$ & $167 \mathrm{~b}$ & $105 \mathrm{c}$ & $114 \mathrm{c}$ & 3 & $* * *$ & 0.50 & $* *$ \\
\hline Total C18 FA, g & 842 & 948 & 1023 & 1123 & 22 & $* * *$ & $* * *$ & 0.88 \\
\hline Total FA, g & 957 & 1085 & 1139 & 1260 & 25 & $* * *$ & $* * *$ & 0.90 \\
\hline \multicolumn{9}{|l|}{ Yield/d } \\
\hline Milk, kg & 24.4 & 25.6 & 23.4 & 23.7 & 1.0 & 0.17 & 0.49 & 0.67 \\
\hline $\mathrm{ECM}^{3}, \mathrm{~kg}$ & 24.8 & 26.3 & 22.0 & 21.7 & 1.0 & $* * *$ & 0.54 & 0.36 \\
\hline Fat, g & 1003 & 1053 & 786 & 726 & 45 & $* * *$ & 0.91 & 0.23 \\
\hline Protein, g & 842 & 933 & 864 & 917 & 36 & 0.92 & 0.06 & 0.60 \\
\hline Lactose, $\mathrm{g}$ & 1175 & 1222 & 1106 & 1124 & 52 & 0.12 & 0.53 & 0.79 \\
\hline \multicolumn{9}{|l|}{ Concentration, $\%$} \\
\hline Fat & 4.16 & 4.13 & 3.41 & 3.05 & 0.13 & $* * *$ & 0.15 & 0.22 \\
\hline Protein & 3.48 & 3.67 & 3.76 & 3.90 & 0.07 & $* *$ & $*$ & 0.76 \\
\hline Lactose & 4.80 & 4.80 & 4.81 & 4.80 & 0.04 & 0.81 & 0.88 & 0.98 \\
\hline
\end{tabular}

${ }^{1}$ Statistical probabilities of treatment differences, $* P<0.05$; $* * P<0.01$; $* * * P<0.001$. Values represent means of the last 4 measurements in the experimental period and means within row with different superscripts differ according to level of significance indicated. $P$ values for non-significant effects are shown.

${ }^{2}$ Calculated on the basis of content of NE in the four diets (Tab. II).

${ }^{3} \mathrm{ECM}=$ milk yield $\times(383 \times$ fat $\%+242 \times$ protein $\%+157.1 \times$ lactose $\%+20.7) / 3140$.

$P<0.001)$. Milk fat percentage decreased in a curvilinear manner with increasing concentrations of trans 10 , cis 12 -CLA and cis9,trans11-CLA (Fig. 2).

\section{DISCUSSION}

To our knowledge, only one study previously compared the effects of maize and grass silage and the proportion of concentrate in the diet on milk production and concentrations of different CLA and transC18:1 isomers in milk [16]. However, in that study, diets were supplemented with $3 \%$ fish and sunflower oil $(2: 3 \mathrm{w} / \mathrm{w})$, so the results should be compared with caution although we included rapeseed cake $(27-31 \%$ of DM) in all four experimental diets to increase the overall content of PUFA. The increase in trans10, cis12-CLA and trans10-C18:1 concentration when maize silage was substituted for grass silage was in line with Shingfield et al. (2005) [16], but on the contrary to our results they did not observe any significant silage type effect on cis9,trans11-CLA. 
Table IV. Effect of grass (G) or maize (M) silage and a low (L) or high (H) level of concentrate on milk fatty acid composition.

\begin{tabular}{|c|c|c|c|c|c|c|c|c|}
\hline \multirow{3}{*}{$\begin{array}{l}\text { Silage type (S) } \\
\text { Concentrate level (C) }\end{array}$} & \multicolumn{4}{|c|}{ Dietary treatment } & \multirow[b]{3}{*}{ SEM } & \multirow{2}{*}{\multicolumn{3}{|c|}{$P^{1}$}} \\
\hline & \multicolumn{2}{|c|}{ G } & \multicolumn{2}{|c|}{$\mathrm{M}$} & & & & \\
\hline & $\mathrm{L}$ & $\mathrm{H}$ & $\mathrm{L}$ & $\mathrm{H}$ & & $\mathrm{S}$ & $\mathrm{C}$ & $\mathrm{S} \times \mathrm{C}$ \\
\hline \multicolumn{9}{|l|}{ FA, g/100 g FA } \\
\hline $\mathrm{C} 4: 0$ & 3.73 & 3.59 & 3.22 & 2.69 & 0.13 & $* * *$ & $*$ & 0.15 \\
\hline C6:0 & 1.94 & 1.97 & 1.51 & 1.36 & 0.08 & $* * *$ & 0.50 & 0.31 \\
\hline $\mathrm{C} 8: 0$ & 1.09 & 1.17 & 0.93 & 0.87 & 0.05 & $* * *$ & 0.82 & 0.20 \\
\hline C10:0 & 2.16 & 2.29 & 1.68 & 1.78 & 0.13 & $* *$ & 0.30 & 0.78 \\
\hline C12:0 & 2.39 & 2.64 & 2.12 & 2.34 & 0.14 & 0.05 & 0.10 & 0.90 \\
\hline C14:0 & 9.73 & 9.79 & 8.71 & 8.59 & 0.28 & $* *$ & 0.92 & 0.76 \\
\hline C16:0 & 22.1 & 21.8 & 19.1 & 18.6 & 0.63 & $* * *$ & 0.51 & 0.90 \\
\hline cis9-C16:1 & 1.30 & 1.42 & 1.70 & 1.94 & 0.16 & $* *$ & 0.29 & 0.70 \\
\hline C18:0 & 13.7 & 13.0 & 11.9 & 11.0 & 0.61 & $* *$ & 0.22 & 0.87 \\
\hline cis9-C18:1 & 25.5 & 25.3 & 27.5 & 27.2 & 0.77 & $*$ & 0.77 & 0.99 \\
\hline trans11-C18:1 & $1.74 \mathrm{a}$ & $1.79 \mathrm{a}$ & $2.80 \mathrm{~b}$ & $1.55 \mathrm{a}$ & 0.25 & 0.11 & $*$ & $*$ \\
\hline trans10-C18:1 & $0.60 \mathrm{a}$ & $0.66 \mathrm{a}$ & $3.14 \mathrm{~b}$ & $6.05 \mathrm{c}$ & 0.55 & $* * *$ & * & * \\
\hline Total trans-C18: $1^{2}$ & 4.86 & 5.08 & 9.25 & 10.53 & 0.46 & $* * *$ & 0.11 & 0.26 \\
\hline cis 9, trans11-CLA & $0.89 \mathrm{a}$ & $0.92 \mathrm{a}$ & $1.61 \mathrm{~b}$ & $1.17 \mathrm{a}$ & 0.10 & $* * *$ & $*$ & $*$ \\
\hline trans10,cis12-CLA & $0.013 \mathrm{a}$ & $0.014 \mathrm{a}$ & $0.024 \mathrm{~b}$ & $0.034 \mathrm{c}$ & 0.002 & $* * *$ & $* *$ & $*$ \\
\hline cis9,cis12-C18:2 & 1.17 & 1.56 & 1.59 & 1.93 & 0.06 & $* * *$ & $* * *$ & 0.66 \\
\hline cis 9, cis 12, cis $15-\mathrm{C} 18: 3$ & 0.63 & 0.64 & 0.36 & 0.41 & 0.02 & $* * *$ & 0.09 & 0.29 \\
\hline$\geq \mathrm{C} 20: 0$ & 0.84 & 0.91 & 0.74 & 0.80 & 0.03 & $* *$ & $*$ & 0.94 \\
\hline Others & 7.50 & 7.47 & 7.66 & 8.24 & 0.19 & $*$ & 0.15 & 0.11 \\
\hline
\end{tabular}

${ }^{1}$ Statistical probabilities of treatment differences, $* P<0.05$; ** $P<0.01 ; * * * P<0.001$. Values represent the mean of the samples collected at the end of weeks $3,4,5$ and 6 in the experimental period and means within row with different superscripts differ according to level of significance indicated. $P$ values for non-significant effects are shown.

${ }^{2}$ Total trans-C18:1 is the sum of; trans $\mathrm{C} 18: 1 n-2$, trans $\mathrm{C} 18: 1 n-6$, trans $\mathrm{C} 18: 1 n-7$, trans $\mathrm{C} 18: 1 n-8$, trans C18:1n-9 and trans $\mathrm{C} 18: 1 n-10$.

A number of studies have demonstrated that increasing amounts of readily digestible carbohydrates in the diet are associated with increased proportions of trans10,cis12-CLA and trans10C18:1 in milk fat $[4-6,16]$. The fact that the concentrate level only affected trans10,cis12-CLA and trans10-C18:1 but also the cis9,trans11-CLA and trans11C18:1 concentration in milk when maize silage was fed, suggests that increased proportions of concentrate (starch) in the diet does not severely affect the ruminal biohydrogenation pattern unless combined with a forage naturally high in starch. An increased ratio of starch to fibre in the diet has been shown to impair the rate of lipolysis of dietary lipids in vitro [17], and is an important factor controlling the formation of 
(a)
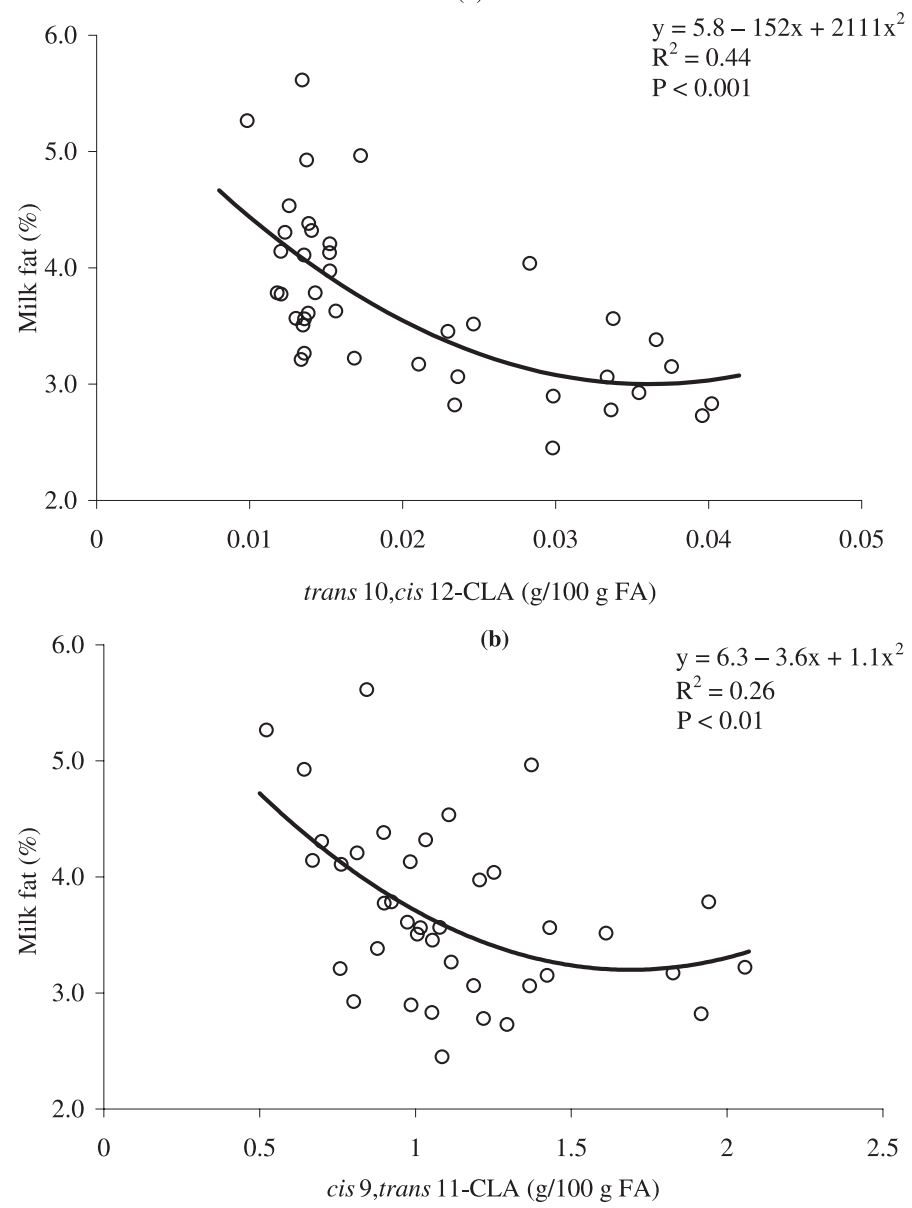

Figure 2. The relationship between milk fat percentage and milk fat content of trans10, cis12-CLA (a) and cis9,trans11-CLA (b). Regression equations, $R^{2}$ and probability are presented for each plot.

individual biohydrogenation intermediates in the rumen [9]. In this experiment, the daily intake of starch accounted for 67 and $54 \%$ of the variation in milk fat trans10,cis12-CLA and trans10-C18:1, respectively (Figs. $3 \mathrm{a}$ and $3 \mathrm{~b}$ ) and the concentration of total trans-C18:1 increased with starch intake (Fig. 3c). High grain diets promote the growth of the bacterial strain Megasphera elsdenii YJ-4 [18] due to a decrease in rumen $\mathrm{pH}$ and cause a rapid decline in the main cellulose digesting bacteria Butyrivibrio fibrisolvens [19]. Megasphera elsdenii YJ-4 exhibits cis9,trans10-isomerase activity [20], which can convert 18:2n-6 to trans10,cis12-CLA and trans10-C18:1, whereas Butyrivibrio fibrisolvens produces cis9,trans11-CLA and trans11-C18:1 as intermediates in the hydrogenation of 18:2n-6 [21]. The large variability in trans $10-\mathrm{C} 18: 1$ and trans10,cis12-CLA concentration in milk from cows fed maize silage diets (Figs. 3a and 3b) may 

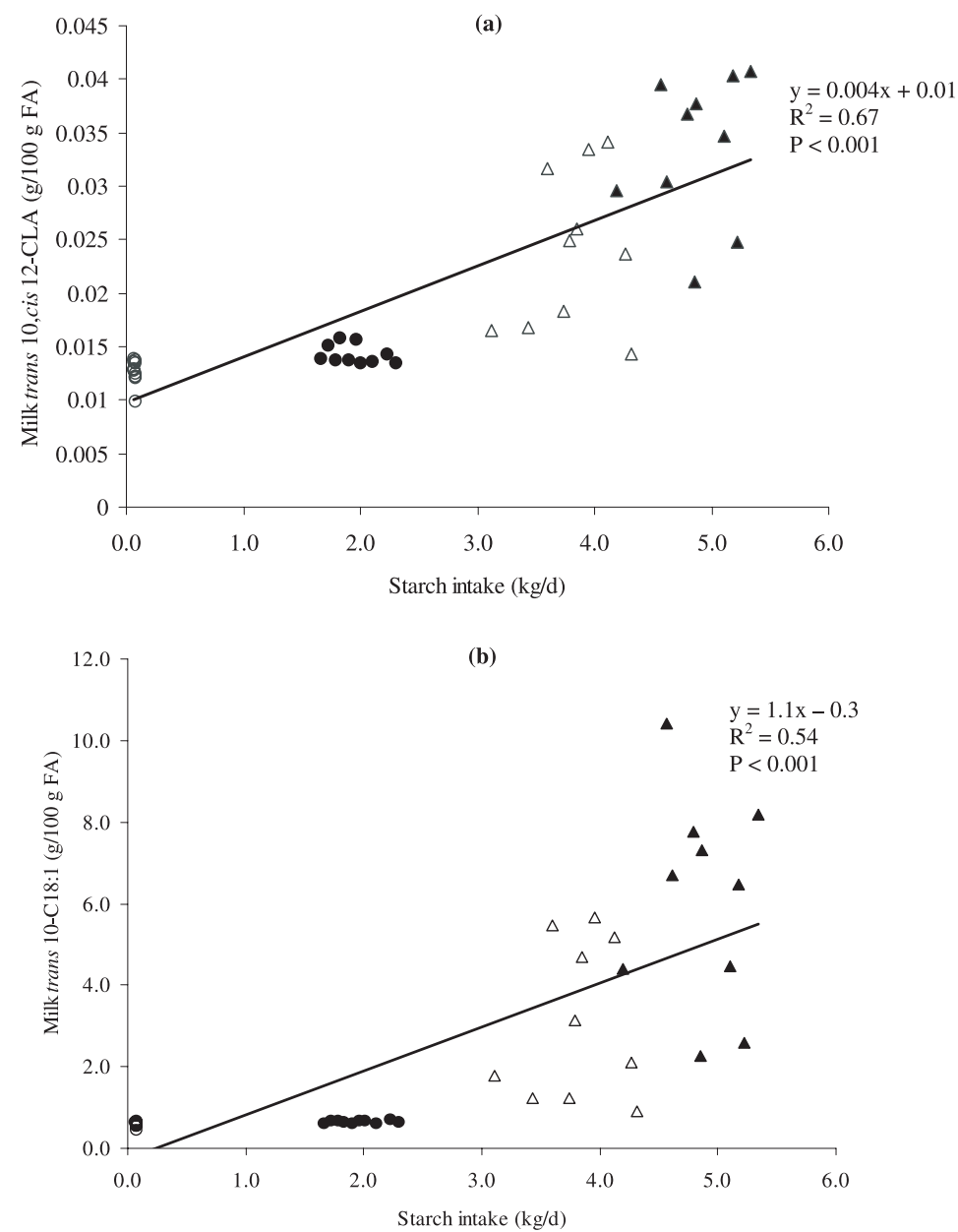

Figure 3. The relationship between the intake of starch across all dietary treatments and concentrations of trans10, cis12-CLA (a), trans10-C18:1 (b), total trans-C18:1 (c) and milk fat (d), for cows given the GL (O) GH $(\bullet)$, ML $(\triangle)$ and $\mathrm{MH}(\boldsymbol{\Delta})$ diets. Regression lines, $R^{2}$ and probability are presented for each plot.

suggest that cows respond differently to high intakes of starch. According to Kim et al. [18], it is conceivable that individual cows may harbour different Megasphera elsdenii strains with different capacities to produce trans10-C18:1 and trans10, cis12CLA, and this may contribute to the larger variability observed on high starch diets.
In accordance with Griinari et al. [4], the results also indicate that relatively large amounts of 18:2n-6 as provided by maize silage diets, is a prerequisite for increased proportions of trans10,cis12-CLA and trans10-C18:1 in milk fat. However, we can not exclude that some of the silage type and concentrate level effects on 

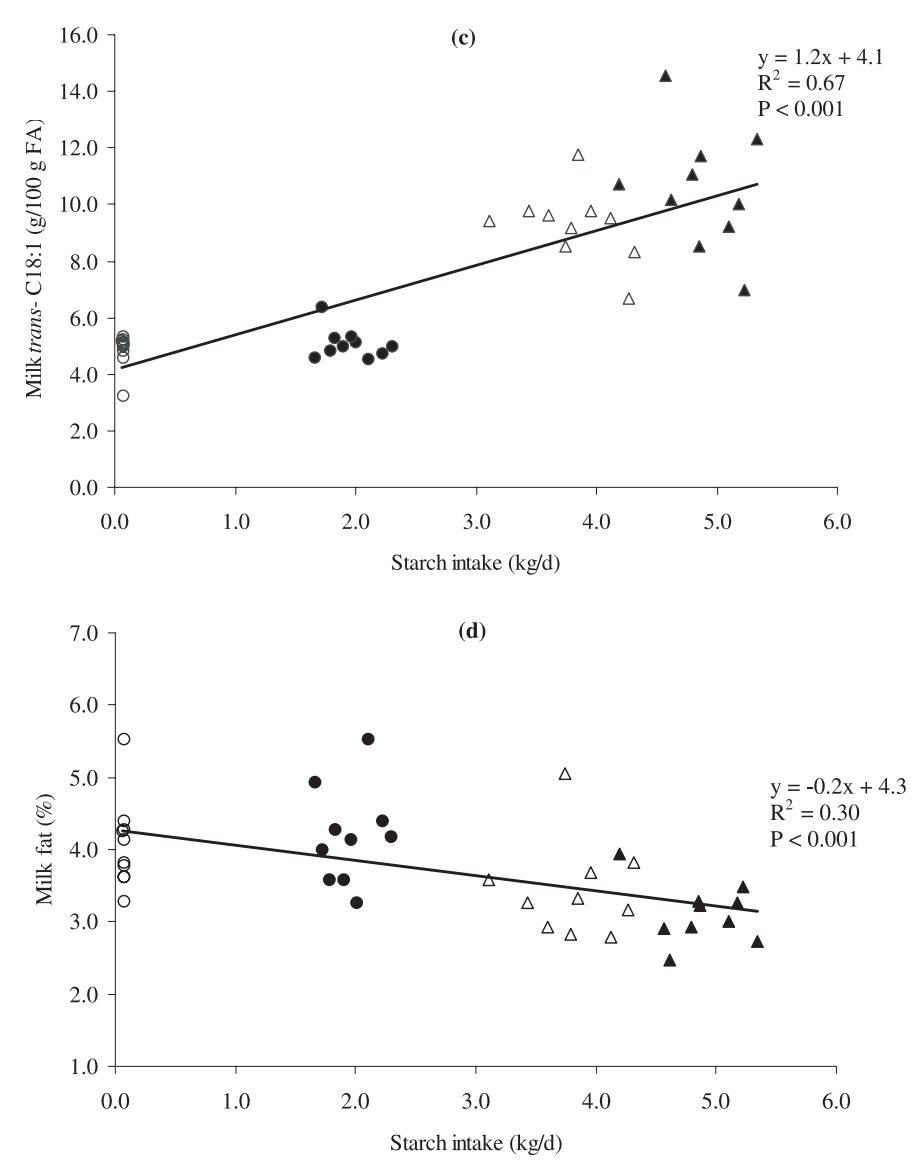

Figure 3. Continued.

trans-C18:1 and CLA isomers in milk to some extent might to some extent be related to the unexpected higher intakes of total $\mathrm{C} 18$ fatty acids for cows fed maize silage (Tab. III), and perhaps also to differences in crude protein contents of maize and grass silage diets (Tab. II).

C18:0 is the end product in the biohydrogenation of PUFA in the rumen, but apart from absorption, the C18:0 concentration in milk also reflects the relative activity of $\Delta^{9}$-desaturase in the mammary gland. The lower C18:0 and the substantially higher total trans-C18:1 in milk from cows fed maize silage may therefore indi- cate a less extensive complete biohydrogenation of PUFA in the rumen and/or a lower $\Delta^{9}$-desaturase activity in the mammary gland, since the differences are not related to a lower intake of total C18 fatty acid for cows fed maize silage (Tab. III).

On the ontrary to our results, feeding maize compared with grass silage is not always associated with significant reductions in milk fat percentage $[22,23]$. The different results can probably be ascribed to variations in chemical composition of maize silages especially in NDF and starch content, and physical characteristics such as particle size of the silages may also be 
important in terms of development of milk fat depression [9] together with the overall composition and amount of PUFA in the total mixed rations.

Concentrate level did not significantly affect milk fat percentage, but compared with studies where milk fat depression has been reported $[6,7]$, the concentrate:forage ratio in our study was rather low for both high and low concentrate diets (50:50 and $30: 70$, respectively). However, the total intake of starch appeared to be a major cause of variation in milk fat percentage (Fig. 3d) in agreement with the results by Shingfield et al. [16].

In accordance with previous studies $[4,5,7]$, the reduction in milk fat percentage was associated with an increase in milk fat trans 10, cis12-CLA concentration. Trans10,cis12-CLA is a potent inhibitor of milk fat synthesis in the mammary gland $[11,24]$, especially by reducing the de novo synthesis of short and medium-chain fatty acids [11]. In agreement with this, maize silage diets resulted in lower short and medium-chain fatty acids (C4:0-C16:0) in milk, compared with grass silage diets. However, Griinari and Bauman [9] summarised that trans 10 ,cis 12 -CLA only accounts for up to $50 \%$ of the reduction in milk fat secretion when dietary milk fat depression is induced, and recently, Loor et al. [25] showed that milk fat trans10,cis12-CLA increased minimally in milk fat depressed cows offered a low forage diet supplemented with linseed oil. This suggests that in addition to trans 10, cis12-CLA, other inhibitors of milk fat synthesis are formed in the rumen when dietary milk fat depression is induced. Cis9,trans11-CLA appeared to be related to the decrease in milk fat percentage in our study, but the correlation between cis 9 ,trans 11 CLA and milk fat was substantially lower $\left(R^{2}=0.26, P<0.01\right)$ than between trans10, cis12-CLA and milk fat $\left(R^{2}=0.44, P<0.001\right)$ (Fig. 2). Furthermore, Lin et al. [26] found that trans 10, cis $12-$ CLA is a much more potent inhibitor of de novo fatty acid synthesis and desaturation than cis9,trans11-CLA in the mammary gland of lactating mice. The trans10-C18:1 isomer is another obvious candidate due to the close relationship with trans10, cis12-CLA $(y=0.003 x+0.012$, $\left.R^{2}=0.91, P<0.001\right)$, but trans 9 , cis $11-$ CLA may also be involved [27] as well as other not yet identified intermediates of ruminal biohydrogenation of PUFA.

In summary, maize silage diets may result in higher concentrations of cis9,trans11-CLA and trans10,cis12-CLA as well as trans10-C18:1 in milk fat and a lower milk fat percentage than grass silage based diets. Furthermore, the results show that a high level of concentrate (grain) does not significantly alter the pattern of PUFA biohydrogenation in the rumen, the concentration of CLA and trans-C18:1 isomers in milk or cause milk fat depression unless provided in combination with forage naturally high in starch and C18:2n-6 such as maize silage.

\section{ACKNOWLEDGEMENTS}

The authors are grateful to Lars Bilde Gildbjerg for support in the handling of data, and to laboratory assistants Zahra Roudaki and Karen Jensen for their technical assistance in the fatty acid analysis. The study was funded by the Danish Dairy Research Foundation and the Danish Research Development Program for Food Technology (FOETEK).

\section{REFERENCES}

[1] Bauman DE, Lock AL, Corl BA, Ip C, Salter AM, Parodi PW. Milk fatty acids and human health: potential role of conjugated linoleic acid and trans fatty acids. In: Sejrsen K, Hvelplund T, Nielsen MO (Eds), Ruminant physiology - Digestion, metabolism and impact of nutrition on gene expression, immunology and stress, Wageningen Acad Publ (NL), 2006, pp 529-561. 
[2] Ritzenthaler KL, McGuire MK, Falen R, Shultz TD, Dasgupta N, McGuire MA. Estimation of conjugated linoleic acid intake by written dietary assessment methodologies underestimates actual intake evaluated by food duplicate methodology. J Nutr 2001, 131: 1548-1554.

[3] Bauman DE, Corl BA, Peterson DG. The biology of conjugated linoleic acids in ruminants. In: Sebedio JL, Christie WW, Adlof RO (Eds), Advances in conjugated linoleic acid research, Vol 2, AOCS Press, Champain, IL, 2003, pp 146-174.

[4] Griinari JM, Dwyer DA, McGuire MA, Bauman DE, Palmquist DL, Nurmela KV. Trans-octadecenoic acids and milk fat depression in lactating dairy cows. J Dairy Sci 1998, 81: 1251-1261.

[5] Piperova LS, Teter BB, Bruckental I, Sampugna J, Mills SE, Yurawecz MP, Fritsche J, Ku K, Erdman RA. Mammary lipogenic enzyme activity, trans fatty acids and conjugated linoleic acids are altered in lactating dairy cows fed a milk fatdepressing diet. J Nutr 2000, 130: 2568 2574.

[6] Kalscheur KF, Teter BB, Piperova LS, Erdman RA. Effect of dietary forage concentration and buffer addition on duodenal flow of trans-C18:1 fatty acids and milk fat production in dairy cows. J Dairy Sci 1997, 80: 2104-2114.

[7] Peterson DG, Matitashvili EA, Bauman DE. Diet-induced milk fat depression in dairy cows results in increased trans-10, cis-12 CLA in milk fat and coordinate suppression of mRNA abundance for mammary enzymes involved in milk fat synthesis. J Nutr 2003, 133: 3098-3102.

[8] Latham MJ, Storry JE, Sharpe ME. Effect of low-roughage diets on the microflora and lipid metabolism in the rumen. Appl Microbiol 1972, 24: 871-877.

[9] Griinari JM, Bauman DE. Milk fat depression: concepts, mechanisms and management. In: Sejrsen K, Hvelplund $\mathrm{T}$, Nielsen MO (Eds), Ruminant physiology Digestion, metabolism and impact of nutrition on gene expression, immunology and stress: Wageningen Acad. Publ. (NL), 2006, pp 389-417.

[10] Morimoto KC, Van Eenennaam AL, DePeters EJ, Medrano JF. Hot topic: Endogenous production of n-3 and n- 6 fatty acids in mammalian cells. J Dairy Sci 2005 88: 1142-1146.

[11] Baumgard LH, Corl BA, Dwyer DA, Saebo A, Bauman DE. Identification of the conjugated linoleic acid isomer that inhibits milk fat synthesis. Am J Physiol Regul Integr Comp Physiol 2000, 278: R179-R184.

[12] Loor JJ, Ferlay A, Ollier A, Ueda K, Doreau M, Chilliard Y. High-concentrate diets and polyunsaturated oils alter trans and conjugated isomers in bovine rumen, blood, and milk. J Dairy Sci 2005, 88: 3986-3999.

[13] Møller J, Thøgersen R, Kjeldsen AM, Weisbjerg MR, Søegaard K, Børsting CF. Fodermiddeltabel - Sammensætning og og foderværdi af fodermidler til kvæg, 2000, Landsudvalget for Kvæg (in Danish).

[14] Olch J, Lees M, Stanley HS. A simple method for isolation and purification of total lipids from animal tissues. J Biol Chem 1957, 497-509.

[15] Christopherson SW, Glass RL. Preparation of milk fat methyl esters by alcoholysis in an essential nonalcoholic solution. J Dairy Sci 1969, 52: 1289-1290.

[16] Shingfield KJ, Reynolds CK, Lupoli B, Toivonen V, Yurawecz MP, Delmonte P, Griinari JM, Grandison AS, Beever DE. Effect of forage type and proportion of concentrate in the diet on milk fatty acid composition in cows given sunflower oil and fish oil. Anim Sci 2005, 80: 225-238.

[17] Gerson T, John A, King ASD. The effects of dietary starch and fibre on the in vitro rates of lipolysis and hydrogenation by sheep rumen digesta. J Agric Sci Cam 1985, 105: 27-30.

[18] Kim YJ, Liu RH, Rychlik JL, Russell JB The enrichment of a ruminal bacterium (Megasphaera elsdenii YJ-4) that produces the trans-10, cis-12 isomer of conjugated linoleic acid. J Appl Microbiol 2002, 92: 976-982.

[19] Klieve AV, Hennessy D, Ouwerkerk D, Forster RJ, Mackie RI, Attwood GT. Establishing populations of Megasphaera elsdenii YE 34 and Butyrivibrio fibrisolvens YE 44 in the rumen of cattle fed high grain diets. J Appl Microbiol 2003, 95: 621-630.

[20] Bauman DE, Griinari JM. Regulation and nutritional manipulation of milk fat: low-fat milk syndrome. Livest Prod Sci 2001, 70: $15-29$. 
[21] Harfoot CG, Hazlewood GP. Lipid metabolism in the rumen. In: Hobsen PN (Ed), The rumen microbial ecosystem, Elsevier Applied Science, London and New York, 1988, pp 285-322.

[22] Bernard JK, West JW, Trammell DS. Effect of replacing corn silage with annual ryegrass silage on nutrient digestibility, intake, and milk yield for lactating dairy cows. J Dairy Sci 2002, 85: 2277-2282.

[23] Fitzgerald JJ, Murphy JJ. A comparison of low starch maize silage and grass silage and the effect of concentrate supplementation of the forages or inclusion of maize grain with the maize silage on milk production by dairy cows. Livest Prod Sci 1999, 57: 95-111.

[24] Peterson DG, Baumgard LH, Bauman DE. Short communication: Milk fat response to low doses of trans-10, cis-12 conjugated linoleic acid (CLA). J Dairy Sci 2002, 85: 1764-1766.

[25] Loor JJ, Ferlay A, Ollier A, Doreau M, Chilliard Y. Relationship among trans and conjugated fatty acids and bovine milk fat yield due to dietary concentrate and linseed oil. J Dairy Sci 2005, 88: 726-740.

[26] Lin X, Loor JJ, Herbein JH. Trans10, cis1218:2 is a more potent inhibitor of de novo fatty acid synthesis and desaturation than cis 9 ,trans 11-18:2 in the mammary gland of lactating mice. J Nutr 2004, 134: 1362-1368.

[27] Perfield JW II, Lock AL, Sæbø A, Griinari JM, Bauman DE. Trans-9,cis-11 conjugated linoleic acid (CLA) reduces milk fat synthesis in lactating dairy cows. J Anim Sci 2005, 83 (Suppl 1): 211. 